\title{
Polarographic Behavior of Manganese(II) in the Presence of Oxalate Ions in Perchlorate and Sulfate Solutions
}

\author{
Jadwiga Urbańska
}

Received: 3 November 2009 / Accepted: 7 July 2010 / Published online: 20 January 2011

(C) The Author(s) 2011. This article is published with open access at Springerlink.com

\begin{abstract}
The dc polarographic method has been applied to study coordination equilibria between $\mathrm{Mn}(\mathrm{II})$ and oxalate ions in perchlorate and sulfate solutions. The stoichiometries of complexes formed in solution and those reduced at a dropping mercury electrode were established. The stability constants of the Mn(II) oxalate and sulfate complexes, as well as their diffusion coefficients, were determined at a constant ionic strength $0.5 \mathrm{~mol} \cdot \mathrm{L}^{-1}$ and $25^{\circ} \mathrm{C}$. The stabilities of these $\mathrm{Mn}$ (II) complexes were compared with the corresponding complexes of other divalent metal ions. The polarographic method was able to identify complexes that have not been established by other methods and to determine their stability constants with high accuracy.
\end{abstract}

Keywords Polarography · Manganese(II) complexes · Oxalate complexes · Stability constants $\cdot$ Electrode reduction mechanism

\section{Introduction}

Manganese is among the metals most frequently used in the industry, which results in elevated levels of this metal in the environment: in water, soil and in biological materials. Manganese is involved in the production of steel (as a hardening agent), and in Mn alloys, dry-cell batteries, and in the chemical industry for coloring glasses, ceramics and pigments, as well as in agriculture as a fertilizer and fungicide (e.g., MANEB, ZINEB). In gasoline, it is applied as anti-knocking agent and to improve octane ratings (MMT). Recently, its compounds have been used as the contrasting agent in nuclear magnetic resonance tomography (Mn-DPDP for liver and pancreas scans) [1,2].

On the other hand, manganese is important in the activation of many enzymes involved in metabolic processes of all organisms. It is required for protein and fat metabolism, for healthy nerves and a healthy immune system, for blood sugar regulation, the production of cellular energy and bone growth [1,3,4]. Manganese elevates the level of anti-oxidative

J. Urbańska (凶)

Faculty of Chemistry, University of Wrocław, 14 F. Joliot-Curie, 50-383 Wrocław, Poland

e-mail: ju@wchuwr.pl 
protection by decreasing the concentration of free radicals [1], assists in the utilization of vitamins $\mathrm{B}_{1}$ and $\mathrm{E}$, and prevents clotting effects [3].

However, increased manganese levels are known to damage the central nervous system, resulting in the motor coordination abnormalities and psychic disorder and, finally, can even result in symptoms similar to Parkinson's disease [1, 4, and references cited therein]. Manganese toxicity is also a serious constraint to crop cultivation since manganese is taken up by plants and can easily be passed into the food chain, again causing symptoms similar to Parkinson's disease [5].

The exact mechanism of toxicity of manganese is not fully understood. To understand better the role of this element in biological reactions, it is necessary to investigate its interaction with various inorganic and organic ligands occurring in the environment, in order to identify which species influence its bioavailability, mobility and toxicity.

A survey of the literature reveals that manganese speciation, in spite of its biological importance, has been rarely investigated [6-9] in comparison to studies of other 3d-electron elements. The polarographic method has seldom been used in manganese coordination equilibria studies [10-13] although, in some favorable cases, it can detect complexes that have not been established by other methods and can be used to determine their stability constants with high accuracy or, at least, comparable to the accuracy achieved by the potentiometric method $[14,15]$.

$\mathrm{Mn}$ (II) is reduced on a mercury electrode at strongly negative potentials, and in acidic media its reduction wave (or that of its complexes) overlaps with the hydrogen ion wave, and thus it is extremely difficult to separate them. On the other hand, in alkaline media Mn(II) precipitates. Secondly, the reduction wave of $\mathrm{Mn}(\mathrm{II})$ to $\mathrm{Mn}(0)$ in some media has a slope higher than that for a fully reversible 2-electron process $[10,16]$, and it is uncertain which equation should be used to determine the stability constants of $\mathrm{Mn}$ (II) complexes, that for a reversible reduction or that for an irreversible one. Application of both equations yields different results.

The purpose of the present work is study Mn(II) speciation that may help in recognizing its beneficial or toxic role in living organisms. The main goal was to demonstrate a simple method of analysis of $\mathrm{Mn}(\mathrm{II})$ waves that provides valuable information concerning the electrode reduction mechanism and to determine stability constants of the complexes. As model systems, the reduction of $\mathrm{Mn}$ (II) in the presence of oxalate ions in perchlorate and sulfate solutions have been chosen. The discharge of $\mathrm{Mn}$ (II) in the presence of oxalate ions in perchlorate solutions was partly studied by Verdier and Piro [10,11]. However, the conclusions reported in that study need to be revised since their detailed analysis of the current-potential curves for the reduction mechanism differed from that proposed in the present paper. The results obtained are presented and discussed below.

\section{Experimental}

Measurements were made on a Radelkis $\mathrm{OH}-105$ polarograph using a dropping mercury electrode. The mercury container was placed at a height of $50 \mathrm{~cm}$, the mercury flow rate was $2.36 \mathrm{mg} \cdot \mathrm{s}^{-1}$, and the resulting drop time $\left(t_{1}\right)$ was $3.8 \mathrm{~s}$. A saturated calomel electrode (SCE) with a large surface area was used as both anode and reference electrode. It was connected to the examined solution with an electrolytic bridge, filled with saturated sodium perchlorate (or sulphate) solution.

All stock solutions were prepared from analytical-reagent grade chemicals. The concentrations of manganese(II) in $\mathrm{MnSO}_{4}$ solutions was fixed at $5 \times 10^{-5} \mathrm{~mol} \cdot \mathrm{L}^{-1}$ while those 
of oxalate $\left(\mathrm{Na}_{2} \mathrm{C}_{2} \mathrm{O}_{4}\right)$ were varied over the range $0.001-0.1500 \mathrm{~mol} \cdot \mathrm{L}^{-1}$. A constant ionic strength equal to $0.5 \mathrm{~mol} \cdot \mathrm{L}^{-1}$ was maintained by adding the necessary amounts of sodium perchlorate or sodium sulfate. The $\mathrm{pH}$ values of all investigated solutions were in the range 6.0-6.5. The $\mathrm{pH}$ values were checked by means of a Radelkis OP-211 digital $\mathrm{pH}$ meter.

All experiments were carried out under an argon atmosphere at $25^{\circ} \mathrm{C}$. The current of interest was recorded as the difference between the total current and the residual current measured in the pure supporting electrolyte and ligand solution at the same potential.

\section{Results and Discussion}

One well-defined polarographic wave was obtained for all of the examined solutions (Fig. 1). The wave shifted towards more negative potentials as the oxalate ions concentration increased and its limiting current decreased in both supporting electrolytes (sodium perchlorate and sodium sulfate), see Fig. 2, indicating the formation of complexes. Logarithmic analyses were performed for all of the waves to determine the half-wave potentials $\left(E_{1 / 2}\right)$ and their slope coefficients $\left(2.303 R T / \alpha n_{\alpha} F\right)$. Some of the curves, characteristic of this investigation, are shown in Fig. 3.

Plots of $\log _{10}\left[i /\left(i_{l}-i\right)\right]$ versus $E$ for the reduction of the free $\mathrm{Mn}$ (II) ion (aqua ion) and of its oxalate complexes formed at concentrations of oxalate lower than $0.03 \mathrm{~mol} \cdot \mathrm{L}^{-1}$, in both supporting electrolytes $\mathrm{NaClO}_{4}$ and $\mathrm{Na}_{2} \mathrm{SO}_{4}$, were straight lines with a slope of $33 \mathrm{mV}$, which is a little higher than that for a fully reversible two-electron process. When the concentration of oxalate ions exceeded $0.03 \mathrm{~mol} \cdot \mathrm{L}^{-1}$, the slope in the lower part of the wave was still $33 \mathrm{mV}$, whereas it increased in the upper part. The half-wave potentials $E_{1 / 2}$ for these waves were obtained by extrapolation of the lower sections of each wave (decreased by $33 \mathrm{mV}$ ) to zero value of $\log _{10}\left[i /\left(i_{l}-i\right)\right]$. The values of $E_{1 / 2}$ obtained plotted against $\log _{10} c_{\mathrm{ox}}$ are presented in Fig. 4.

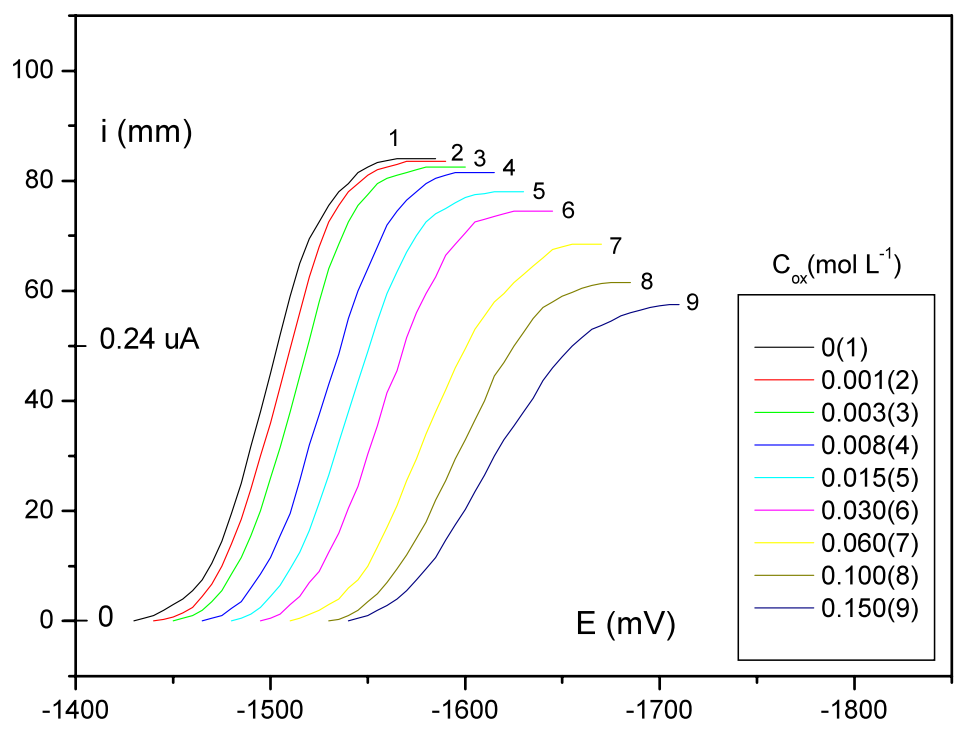

Fig. 1 Selected polarographic waves for $\mathrm{Mn}(\mathrm{II})-$ oxalate complexes in $0.5 \mathrm{~mol} \cdot \mathrm{L}^{-1} \mathrm{NaClO}_{4}$ 


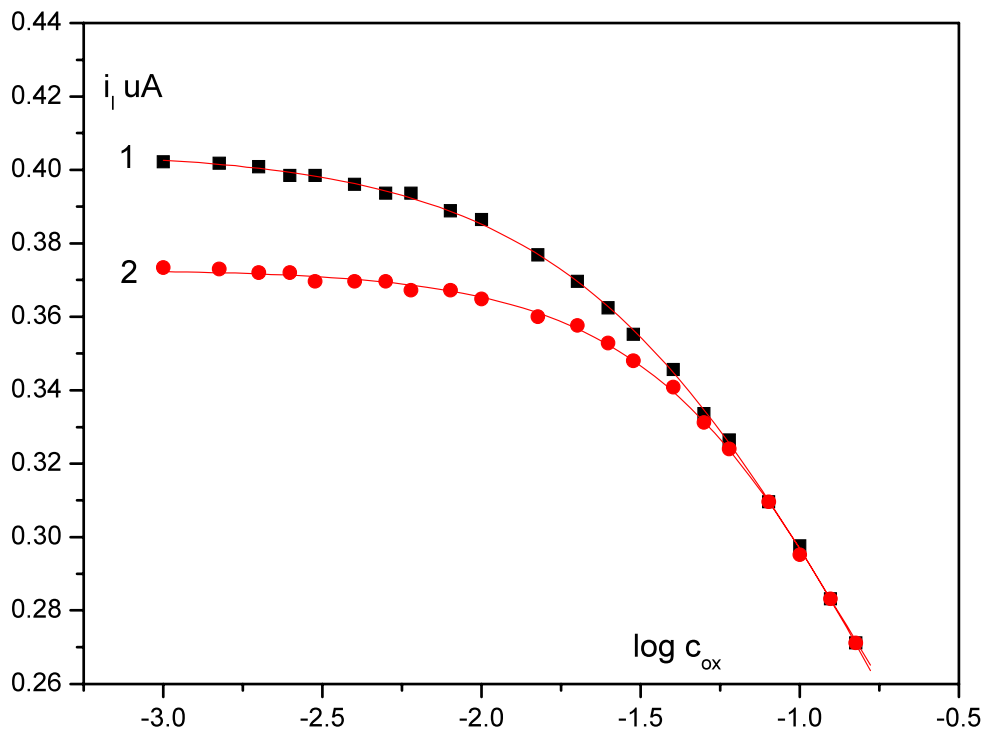

Fig. 2 Dependence of the limiting current on $\log _{10} c_{\mathrm{Ox}}$ in $\mathrm{NaClO}_{4}(1)$ and in $\mathrm{Na}_{2} \mathrm{SO}_{4}$ (2) solutions

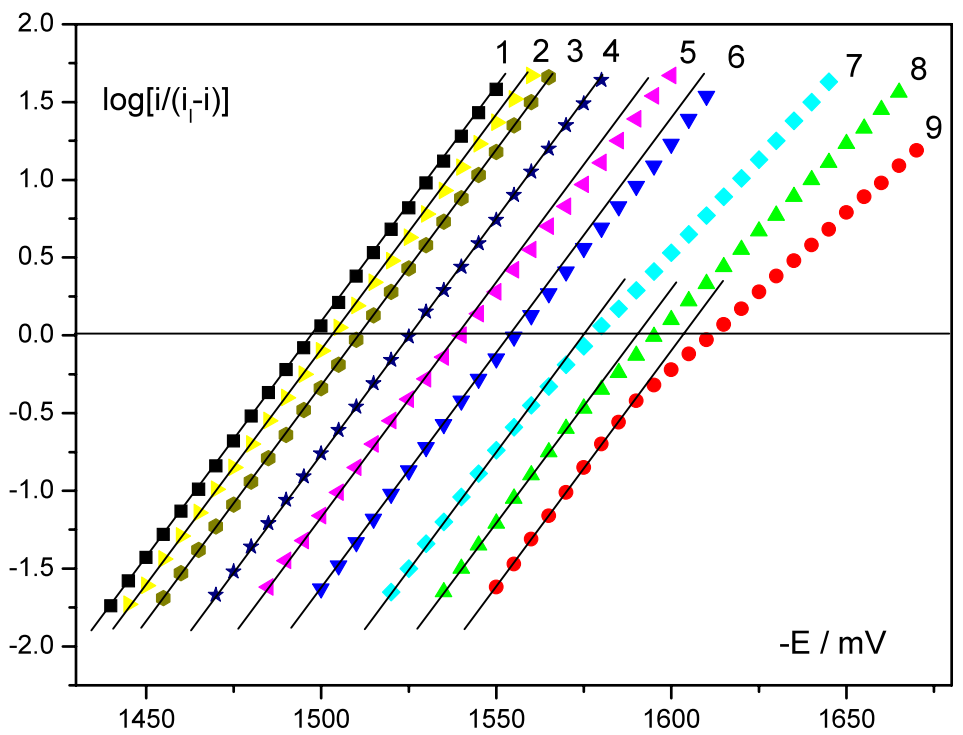

Fig. 3 Selected logarithmic wave analysis for $\mathrm{Mn}(\mathrm{II})-$ oxalate complexes in $0.5 \mathrm{~mol} \cdot \mathrm{L}^{-1} \mathrm{NaClO}_{4} c_{\mathrm{Ox}}: 0$ (1), $0.001(2), 0.003(3), 0.008(4), 0.015(5), 0.03(6), 0.06(7), 0.10(8)$, and $0.15(9) \mathrm{mol} \cdot \mathrm{L}^{-1}$

This method of determination of the half-wave potential of the wave was previously applied in the $\mathrm{Ni}(\mathrm{II})$-oxalate system [17], and the stability constants of the complexes determined from the shift of this potential with respect to the oxalate ions concentration produced values very close to those obtained in a different way by Crow [18]. 


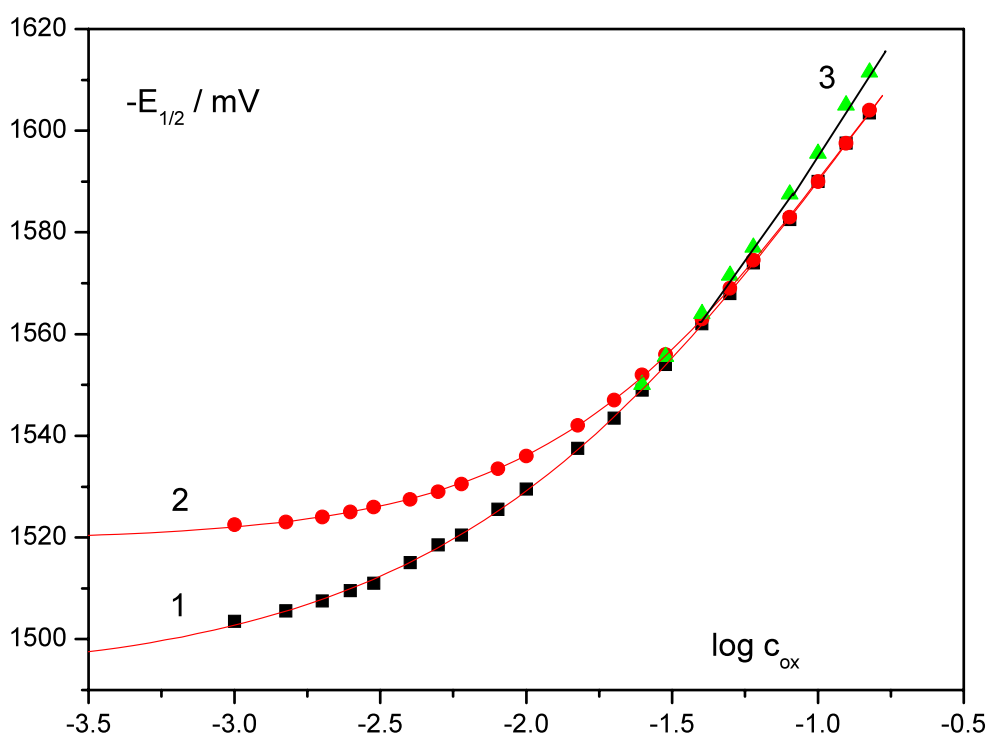

Fig. 4 Changes in the half-wave potentials of $\mathrm{Mn}$ (II) with $\log _{10} c_{\mathrm{Ox}}$ in $\mathrm{NaClO}_{4}$ (1 and 3) and in $\mathrm{Na}_{2} \mathrm{SO}_{4}$ ( 2 and 3 ) solutions; for curves 1 and 2, the $E_{1 / 2}$ values were obtained from the wave with slope of $33 \mathrm{mV}$, whereas the values for curve 3 were taken directly from the logarithmic curve

Agreement of the slope for reduction of the free $\mathrm{Mn}$ (II) ion in perchlorate solution with that for reduction of $\mathrm{Mn}(\mathrm{II})$ oxalate complexes indicated a common character of the electrode process mechanisms in both electrolytes, i.e. reduction of the $\mathrm{Mn}$ (II) aqua ion [19]. However, following the Brönsted theory, the perchlorate ion cannot form complexes with $\mathrm{Mn}(\mathrm{II})$ but the sulfate ion has same tendency for complexation. The results for these systems are discussed separately below.

\subsection{Reduction of $\mathrm{Mn}(\mathrm{II})$ in $\mathrm{NaClO}_{4}$ Solutions}

To determine the stoichiometry of $\mathrm{Mn}(\mathrm{II})$-oxalate complexes formed in solution, two tests were performed: plotting $\Delta E_{1 / 2}$ versus $\log _{10} c_{\mathrm{ox}}$ and plotting $\log _{10}\left[i /\left(i_{l}-i\right)\right]$ versus $\log _{10} c_{\mathrm{ox}}$ at a fixed potential $E$. The slope of both plots gave the difference in the average ligand numbers between the complexes predominating in the solution and those that were directly reduced at the mercury electrode [19].

The limiting slope of the plot $\Delta E_{1 / 2}$ versus $\log _{10} c_{\text {ox }}$ was 2.32 for $\left(E_{1 / 2}\right)_{c}$ extrapolated from the lower part of the wave, and 2.51 for $\left(E_{1 / 2}\right)_{c}$ taken directly from the logarithmic curve. In the sulfate solutions these values were 2.39 and 2.50 respectively.

The diagram of $\log _{10}\left[i /\left(i_{l}-i\right)\right]$ versus $\log _{10} c_{\mathrm{ox}}$ plotted at the three potentials -1.53 , -1.56 and $-1.59 \mathrm{~V}$ (Fig. 5), at oxalate concentration higher than $0.03 \mathrm{~mol} \cdot \mathrm{L}^{-1}$, gave a difference in the average ligand numbers of 2.40 . These results evidently confirm that, in this system, only the free $\mathrm{Mn}(\mathrm{II})$ aqua ion undergoes direct reduction at the mercury electrode, whereas in the solutions there exist three oxalate complexes: $\mathrm{Mn}(\mathrm{ox}), \mathrm{Mn}(\mathrm{ox})_{2}^{2-}$ and $\mathrm{Mn}(\mathrm{ox})_{3}^{4-}$. When any other species besides of the free $\mathrm{Mn}(\mathrm{II})$ ion is reduced at the electrode, then the difference of the average ligand numbers should be less than two. These results differ from those obtained by Verdier and Piro [10]. They have stated that Mn(II) formed only two oxalate complexes, i.e. $\mathrm{Mn}(\mathrm{ox})$ and $\mathrm{Mn}(\mathrm{ox})_{2}^{2-}$, and that both, together with $\mathrm{Mn}$ (II) aqua ion, were reduced irreversibly at the mercury electrode. 


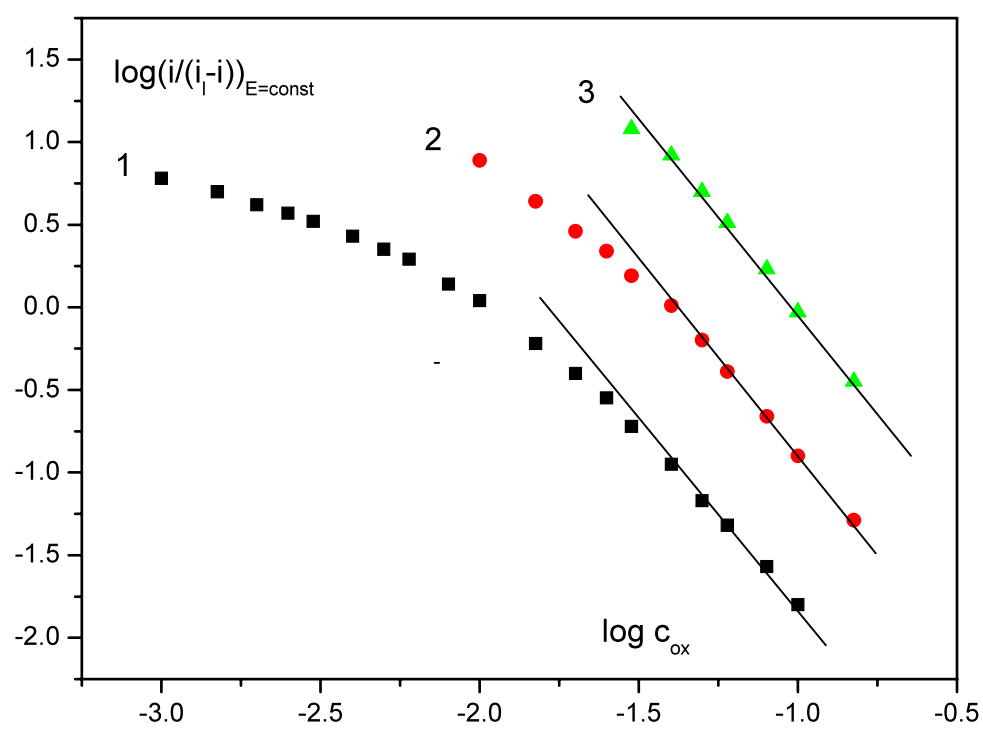

Fig. 5 Variation of $\log _{10}\left[i /\left(i_{l}-i\right)\right]$ with $\log _{10} c_{\mathrm{Ox}}$ at fixed potentials of: $-1.53 \mathrm{~V}(1),-1.56 \mathrm{~V}(2)$, and $-1.59 \mathrm{~V}(3)$ in $\mathrm{NaClO}_{4}$ solutions

The overall stability constants of these complexes were calculated from the relation given by Biernat [20], based on a modification of the DeFord and Hume equation [21], which consists in replacing $n$ by $\alpha n_{\alpha}$. Thus, the modified De Ford and Hume equation can be formulated as:

$$
F_{0}\left(c_{\mathrm{ox}}\right)=\sum \beta_{j} c_{\mathrm{ox}}^{j}=\operatorname{antilog}\left\{0.434\left(\alpha n_{\alpha} F / R T\right)\left[\left(E_{1 / 2}\right)_{s}-\left(E_{1 / 2}\right)_{c}\right]+\log _{10}\left[\left(i_{l}\right)_{s} /\left(i_{l}\right)_{c}\right]\right\}
$$

where $F_{0}\left(c_{\mathrm{ox}}\right)$ is a polynomial function representing the sum of $\beta_{j} c_{\mathrm{ox}}^{j}$ for all complexes, $\beta_{j}$ is the overall stability constant of the $j$-th complex, $c_{\mathrm{ox}}$ is the oxalate ion concentration, $\alpha n_{\alpha}$ is the transfer coefficient of the electrode reaction $(\alpha<1), E_{1 / 2}$ is the half-wave potential, and $i_{l}$ is the limiting current of the wave (the subscripts $\mathrm{s}$ and c refer to the simple and complex ions, respectively). $R, T$ and $F$ have their usual meanings.

The $\log _{10}\left[\left(i_{l}\right)_{s} /\left(i_{l}\right)_{c}\right]$ term in the $F_{0}\left(c_{\mathrm{ox}}\right)$ function was neglected in calculations at high concentrations of oxalate ions since $\left(E_{1 / 2}\right)_{c}$ was extrapolated from the lower part of the wave.

Stability constants of complexes were obtained as follows:

$$
F_{0}\left(c_{\mathrm{ox}}\right)=\sum \beta_{j} c_{\mathrm{ox}}^{j}=\beta_{0}+\beta_{1} c_{\mathrm{ox}}+\beta_{2} c_{\mathrm{ox}}^{2}+\beta_{3} c_{\mathrm{ox}}^{3}
$$

where $\beta_{0}=1$. The function $F_{1}\left(c_{\mathrm{ox}}\right)$ is also introduced:

$$
F_{1}\left(c_{\mathrm{ox}}\right)=\left(F_{0}\left(c_{\mathrm{ox}}\right)-1\right) / c_{\mathrm{ox}}=\beta_{1}+\beta_{2} c_{\mathrm{ox}}+\beta_{3} c_{\mathrm{ox}}^{2}
$$

A plot of $F_{1}\left(c_{\mathrm{ox}}\right)$ values against the oxalate ion concentration yields a curve from which values of $\beta_{j}$ were determined numerically using a commercial computer program in conjunction with the non-linear least-square regression method. The stability constants obtained are: $\beta_{1}=10^{2.65}, \beta_{2}=10^{4.54}$ and $\beta_{3}=10^{5.38}$. All constants were determined with errors not exceeding 0.02 logarithmic units. The use of the unmodified form of the De Ford-Hume 
Table 1 Published stability constants for Mn(II)-oxalate complexes

\begin{tabular}{|c|c|c|c|c|c|c|}
\hline Method & $\begin{array}{l}\text { Medium/ } \\
\text { mol } \cdot \mathrm{L}^{-1}\end{array}$ & $\begin{array}{l}\text { Temp./ } \\
{ }^{\circ} \mathrm{C}\end{array}$ & $\log _{10} \beta_{1}$ & $\log _{10} \beta_{2}$ & $\log _{10} \beta_{3}$ & Ref. \\
\hline \multirow[t]{3}{*}{ Glass electrode } & $0.1 \mathrm{KNO}_{3}$ & 35 & 5.14 & & & {$[22]$} \\
\hline & 0.1 & 25 & 3.9 & & & [23] \\
\hline & $\rightarrow 0$ & $0-45$ & $3.92-4.06$ & & & [24] \\
\hline Conductometric & $\rightarrow 0$ & 18 & 3.89 & & & {$[25]$} \\
\hline \multirow[t]{2}{*}{ Solubility } & $\rightarrow 0$ & 25 & 3.82 & 5.25 & & [25] \\
\hline & $\rightarrow 0$ & 25 & 3.96 & & & [26] \\
\hline $\begin{array}{l}\text { Distribution between } \\
\text { two phases }\end{array}$ & $0.1 \mathrm{KClO}_{4}$ & 20 & 3.75 & & & [27] \\
\hline \multirow[t]{4}{*}{ Polarographic } & $\begin{array}{l}0.1 \mathrm{NaClO}_{4} \\
\left(\mathrm{LiClO}_{4}\right)\end{array}$ & 25 & 3.15 & 4.41 & & [11] \\
\hline & $0.4 \mathrm{NaClO}_{4}$ & 25 & 3.15 & 4.31 & & [10] \\
\hline & $0.5 \mathrm{NaClO}_{4}$ & 25 & 2.65 & 4.54 & 5.38 & Present work \\
\hline & & & $2.72^{\mathrm{a}}$ & $4.67^{\mathrm{a}}$ & $5.91^{\mathrm{a}}$ & \\
\hline
\end{tabular}

${ }^{\mathrm{a} C a l c u l a t e d}$ assuming a fully reversible $2 \mathrm{e}^{-}$process

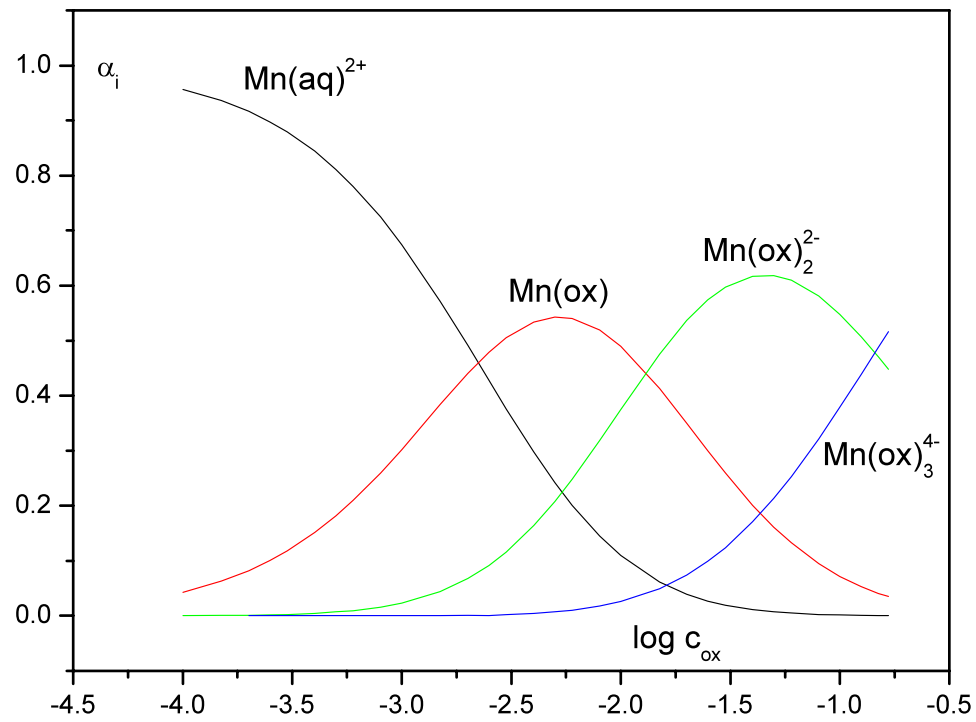

Fig. 6 Distribution of $\mathrm{Mn}(\mathrm{II})$ among different oxalate forms as a function of $\log _{10} c_{\mathrm{Ox}}$ in $\mathrm{NaClO}_{4}$ solutions

equation (i.e., assuming a fully reversible process) gave somewhat higher values of $\beta_{j}$ relative to those obtained from the modified form: $\beta_{1}=10^{2.72}, \beta_{2}=10^{4.67}$ and $\beta_{3}=10^{5.91}$. Stability constants reported by other authors are summarized in Table 1 . The distribution of $\mathrm{Mn}$ (II) among various species is presented in Fig. 6 as a function of $\log _{10} c_{\mathrm{ox}}$.

The majority of literature studies report the stability constant only for the first oxalate complex [22-27]. Generally, the value of $\log _{10} \beta_{1}$ obtained herewith is $1.1-1.3$ units lower than the corresponding values obtained by other methods, both at an ionic strength of 
$0.1 \mathrm{~mol} \cdot \mathrm{L}^{-1}$ or extrapolated to zero concentration, but is approximately equal to that obtained polarographically by Verdier and Piro $[10,11]$. In turn, the $\log _{10} \beta_{2}$ value displays good concordance with Verdier and Piro's values obtained at ionic strengths of 0.1 and $0.4 \mathrm{~mol} \cdot \mathrm{L}^{-1}$. No data were found in the literature for the stability constant of the third complex.

Increasing the oxalate ion concentration is accompanied by a decrease in the limiting current of the waves. At a concentration of $0.15 \mathrm{~mol} \cdot \mathrm{L}^{-1}$, its value was $67.3 \%$ of the limiting current of the $\mathrm{Mn}(\mathrm{II})$ wave in the absence of oxalate ions, but it is still diffusion controlled. This is illustrated by the linear dependence of $i_{l}$ with $h^{1 / 2}$.

From examining changes in the distribution diagram for complexes with changes in the oxalate ion concentration (Fig. 6), it follows that at an oxalate concentration of $0.15 \mathrm{~mol} \cdot \mathrm{L}^{-1}$ there is $48.1 \% \mathrm{Mn}(\mathrm{ox})_{3}^{4-}$ present. This suggests that this complex was inactive polarographically, and the limiting current was dependent only upon the concentrations of the remaining forms in solution.

According to the basic equation of Ilkovič, the intensity of the diffusion limiting current at any given condition is proportional to the concentration of the reduced component [28]:

$$
i_{l}=k \cdot c
$$

where

$$
k=6.3 n F D_{\mathrm{av}}^{1 / 2} m^{2 / 3} t_{1}^{1 / 6}
$$

For a constant difference of mercury levels between the container and capillary, the $k$ value depends only upon the diffusion coefficient. Thus, measurement of the limiting current of the wave at an appropriate concentration of oxalate ions allows determination of the value of average diffusion coefficient of complexes, $D_{\mathrm{av}}$, whose values are presented in Table 2 .

The average diffusion coefficient of complexes, on the other hand, is expressed in the general form as:

$$
D_{\mathrm{av}}=\frac{\sum_{0}^{3} D_{j} \beta_{j} c_{\mathrm{ox}}^{j}}{\sum_{0}^{3} \beta_{j} \mathrm{c}_{\mathrm{ox}}^{j}}
$$

or

$$
D_{\mathrm{av}}=x_{0} D_{0}+x_{1} D_{1}+x_{2} D_{2}+x_{3} D_{3}
$$

where

$$
x_{j}=\frac{\beta_{j} c_{\mathrm{ox}}^{j}}{\sum_{0}^{3} \beta_{j} c_{\mathrm{ox}}^{j}}
$$

Equation 7 allows the possibility of calculating the diffusion coefficients for all species present in the solution at equilibrium. To do an evaluation it was necessary to calculate values of $x_{0}$ in terms of the previously determined formation constants. The diffusion coefficient for the $\mathrm{Mn}$ (II) aqua ion was calculated from the limiting current of its wave in the absence of oxalate.

The diffusion coefficients of individual complex species were calculated using the equation:

$$
\frac{\left(D_{\mathrm{av}}-x_{0} D_{0}\right) \sum_{0}^{3} \beta_{j} c_{\mathrm{ox}}^{j}}{c_{\mathrm{ox}}}=\beta_{1} D_{1}+\beta_{2} D_{2} c_{\mathrm{ox}}+\beta_{3} D_{3} c_{\mathrm{ox}}^{2}=Z
$$


Table 2 Values of the limiting currents $\left(i_{l}\right)$, average diffusion coefficient $\left(D_{\mathrm{av}}\right)$, and average number of oxalate ions coordinated to the $\mathrm{Mn}(\mathrm{II})$ ion $\left(j_{\mathrm{av}}\right)$ as a function of the oxalate ion concentration in $\mathrm{NaClO}_{4}$ and $\mathrm{Na}_{2} \mathrm{SO}_{4}$ solutions at $25^{\circ} \mathrm{C}$

\begin{tabular}{|c|c|c|c|c|c|c|}
\hline \multirow{2}{*}{$\begin{array}{l}c_{\mathrm{OX}} / \\
\mathrm{mol} \cdot \mathrm{L}^{-1}\end{array}$} & \multicolumn{3}{|l|}{$\mathrm{NaClO}_{4}$} & \multicolumn{3}{|l|}{$\mathrm{Na}_{2} \mathrm{SO}_{4}$} \\
\hline & $\begin{array}{l}i_{l} / \\
\mu \mathrm{A}\end{array}$ & $\begin{array}{l}D_{\text {av }} \times 10^{6} / \\
\mathrm{cm}^{2} \cdot \mathrm{s}^{-1}\end{array}$ & $j_{\mathrm{av}}$ & $\begin{array}{l}i_{l} / \\
\mu \mathrm{A}\end{array}$ & $\begin{array}{l}D_{\text {av }} \times 10^{6} / \\
\mathrm{cm}^{2} \cdot \mathrm{s}^{-1}\end{array}$ & $j_{\mathrm{av}}$ \\
\hline 0 & 0.4032 & 9.00 & & 0.3744 & 7.76 & \\
\hline 0.0010 & 0.4025 & 8.97 & 0.35 & 0.3731 & 7.70 & 0.13 \\
\hline 0.0015 & 0.4018 & 8.94 & 0.47 & 0.3722 & 7.67 & 0.19 \\
\hline 0.0020 & 0.4008 & 8.89 & 0.58 & 0.3717 & 7.65 & 0.25 \\
\hline 0.0025 & 0.3996 & 8.84 & 0.67 & 0.3710 & 7.62 & 0.30 \\
\hline 0.0030 & 0.3989 & 8.81 & 0.75 & 0.3703 & 7.59 & 0.36 \\
\hline 0.0040 & 0.3969 & 8.72 & 0.88 & 0.3696 & 7.56 & 0.46 \\
\hline 0.0050 & 0.3936 & 8.58 & 0.98 & 0.3688 & 7.53 & 0.56 \\
\hline 0.0060 & 0.3936 & 8.58 & 1.07 & 0.3681 & 7.50 & 0.65 \\
\hline 0.0080 & 0.3888 & 8.37 & 1.21 & 0.3664 & 7.43 & 0.81 \\
\hline 0.0100 & 0.3849 & 8.20 & 1.32 & 0.3648 & 7.37 & 0.94 \\
\hline 0.0150 & 0.3768 & 7.86 & 1.51 & 0.3611 & 7.22 & 1.21 \\
\hline 0.0200 & 0.3693 & 7.55 & 1.64 & 0.3570 & 7.05 & 1.40 \\
\hline 0.0250 & 0.3624 & 7.27 & 1.75 & 0.3528 & 6.89 & 1.54 \\
\hline 0.0300 & 0.3552 & 6.98 & 1.83 & 0.3480 & 6.70 & 1.66 \\
\hline 0.0400 & 0.3445 & 6.57 & 1.95 & 0.3400 & 6.40 & 1.83 \\
\hline 0.0500 & 0.3346 & 6.20 & 2.04 & 0.3312 & 6.07 & 1.95 \\
\hline 0.0600 & 0.3262 & 5.89 & 2.11 & 0.3237 & 5.80 & 2.04 \\
\hline 0.0800 & 0.3103 & 5.33 & 2.22 & 0.3096 & 5.30 & 2.18 \\
\hline 0.1000 & 0.2976 & 4.90 & 2.30 & 0.2967 & 4.87 & 2.28 \\
\hline 0.01250 & 0.2832 & 4.44 & 2.38 & 0.2832 & 4.44 & 2.37 \\
\hline 0.1500 & 0.2712 & 4.07 & 2.44 & 0.2712 & 4.07 & 2.43 \\
\hline
\end{tabular}

Table 3 Values of the diffusion coefficients of individual complex species in the $\mathrm{Mn}(\mathrm{II})$-oxalate system at $25^{\circ} \mathrm{C}$

\begin{tabular}{ll}
\hline Species & $10^{6} \times D / \mathrm{cm}^{2} \mathrm{~s}^{-1}$ \\
\hline $\mathrm{Mn}(\mathrm{aq})^{2+}$ & 9.00 \\
$\mathrm{Mn}(\mathrm{ox})$ & 9.02 \\
$\mathrm{Mn}(\mathrm{ox})_{2}^{2-}$ & 7.44 \\
$\left.\mathrm{Mn}_{\mathrm{ox}}\right)_{3}^{4-}$ & 0.40 \\
$\mathrm{MnSO}_{4}$ & 7.45 \\
$\mathrm{MnSO}_{4}(\mathrm{ox})^{2-}$ & 3.20 \\
\hline
\end{tabular}

First, the graph of $Z$ versus $c_{\mathrm{ox}}$ was plotted and the values of $\beta_{j} D_{j}$ were determined numerically using a commercial computer program in conjunction with a nonlinear least-square regression method. Because the values of $\beta_{j}$ are already known, it was thus possible to calculate the values of $D_{j}$ for all species. Their values are collected in Table 3 . The contribution of the diffusion coefficient of each particular complex species (the values of $x_{j} D_{j}$ ) to the average diffusion coefficient $D_{\mathrm{av}}$ is shown in Fig. 7. 


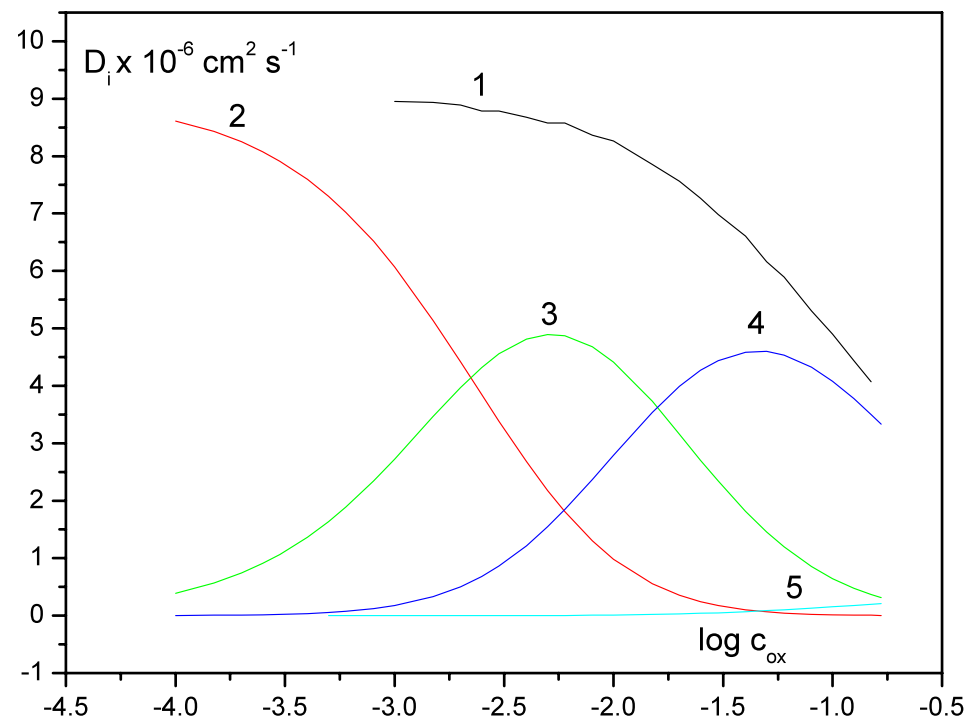

Fig. 7 The average diffusion coefficient $\left(D_{\mathrm{av}}\right)$ as a function of $\log _{10} c_{\mathrm{Ox}}$ in $\mathrm{NaClO}_{4}$ solutions $(1)$, and the contributions of individual $\mathrm{Mn}(\mathrm{II})-\mathrm{oxalate}$ complexes to the average diffusion coefficients: $\mathrm{Mn}(\mathrm{aq})^{2+}(2)$, $\operatorname{Mn}(\mathrm{ox})(3), \operatorname{Mn}(\mathrm{ox})_{2}^{2-}$ (4), and $\operatorname{Mn}(\mathrm{ox})_{3}^{4-}$ (5)

As expected, the diffusion coefficient of the species $\mathrm{Mn}(\mathrm{ox})_{3}^{4-}$ is extremely low in comparison with the diffusion coefficients of other species, and thus its flow to the electrode surface is almost negligible. The very slow diffusion of the large and negatively charged $\mathrm{Mn}(\mathrm{ox})_{3}^{4-}$ complex molecule to the strongly negative charged mercury electrode lowers the concentration of the electroactive form at the electrode surface, resulted in a decrease of the limiting current with increase of oxalate ions concentration in the solution. On the other hand, the species $\mathrm{Mn}(\mathrm{ox})$ is uncharged and its diffusion coefficient slightly exceeds that of the $\mathrm{Mn}(\mathrm{II})$ aqua ion. Similar phenomena were observed earlier in the Ni(II)-oxalate system [17], but for that system the difference between the diffusion coefficients of those two forms was more evident.

Summarizing the results obtained above, the electrode reduction of Mn(II)-oxalate complexes in aqueous $\mathrm{NaClO}_{4}$ solutions can be expressed by the following scheme:

$$
\begin{aligned}
& \operatorname{Mn}(\mathrm{aq})^{2+} \rightleftarrows \mathrm{Mn}(\mathrm{ox}) \rightleftarrows \mathrm{Mn}(\mathrm{ox})_{2}^{2-} \rightleftarrows \mathrm{Mn}(\mathrm{ox})_{3}^{4-} \\
& \qquad \begin{array}{l}
E_{1 / 2}=-1.4975 \mathrm{~V} \\
2.303 R T / \alpha n_{\alpha} F=0.033 \mathrm{~V}
\end{array} \\
& \mathrm{Mn}(\mathrm{Hg})
\end{aligned}
$$

\subsection{Reduction of $\mathrm{Mn}(\mathrm{II})$ in $\mathrm{Na}_{2} \mathrm{SO}_{4}$ Solutions}

The replacement of perchlorate ions by sulfate ions in the solution caused the half-wave potential of the $\mathrm{Mn}$ (II) reduction wave to shift by $21 \mathrm{mV}$ towards more negative values and simultaneously diminished its limiting current. This indicated that $\mathrm{Mn}$ (II) ions formed complexes with sulfate ions. 


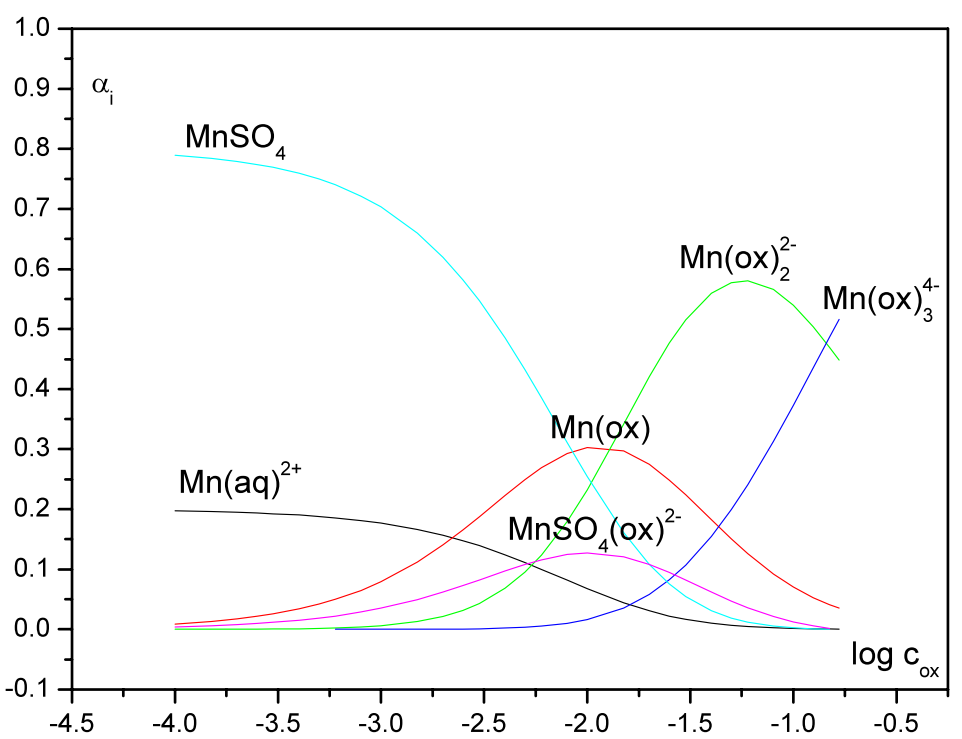

Fig. 8 Distribution of $\mathrm{Mn}(\mathrm{II})$ among various complex species as a function of $\log _{10} c_{\mathrm{OX}}$ in $\mathrm{Na}_{2} \mathrm{SO}_{4}$ solutions

Several potentiometric and conductometric literature studies reported the formation of only one $\mathrm{Mn}(\mathrm{II})$-sulfate complex with stability constant $\beta_{1}$ values falling within the range $10^{2.28}$ to $10^{2.40}$ [6-8], whereas Jain et al. [29] reported from polarographic measurements the formation of three complexes, $\mathrm{Mn}\left(\mathrm{SO}_{4}\right), \mathrm{Mn}\left(\mathrm{SO}_{4}\right)_{2}^{2-}$ and $\mathrm{Mn}\left(\mathrm{SO}_{4}\right)_{3}^{4-}$, with stability constants $\beta=8.5,9.0$ and 93 , respectively. The last value seems to be rather unlikely.

In our study the concentrations of sulfate ions in the solution were decreased with increasing oxalate ion concentration, from $0.1667 \mathrm{~mol} \cdot \mathrm{L}^{-1}$ to zero, because the sulfate ions were substituted by oxalate ions while keeping the ionic strength constant.

The separate study of complexation of $\mathrm{Mn}$ (II) ions with sulfate ions showed that $E_{1 / 2}$ of $\mathrm{Mn}(\mathrm{II})$ reduction wave changes linearly with $\log _{10}\left[\mathrm{SO}_{4}^{2-}\right]$ in the studied range of sulfate ion concentrations. This fact implies the formation of a single $\mathrm{Mn}\left(\mathrm{SO}_{4}\right)$ species. Its stability constant $\beta_{1}$ was estimated to be 24 . Although the obtained value of $\beta_{1}$ is ten times lower than reported in the literature it seems to be quite reliable, and correlates well with respective values obtained polarographically for other metal ions, e.g., for $\mathrm{Ni}(\mathrm{II})$ [30, 31], $\mathrm{Cd}$ (II) [32], and $\mathrm{Zn}$ (II) [33].

Thus, in sulfate solutions $\mathrm{Mn}(\mathrm{II})$ is present as mixtures of the $\mathrm{Mn}(\mathrm{II})$ aqua ion and $\mathrm{Mn}-$ $\mathrm{SO}_{4}$ complexes. Addition of oxalate ions to sulfate solutions simultaneously results in the formation of $\mathrm{Mn}(\mathrm{II})-$ oxalate complexes and a decrease in the concentrations of $\mathrm{MnSO}_{4}$ complexes.

Taking the values of the stability constants for $\mathrm{MnSO}_{4}$ and of the three $\mathrm{Mn}$ (II)-oxalate complexes obtained as described above, the expected values of $E_{1 / 2}$ were estimated for the $\mathrm{Mn}$ (II) reduction wave at various concentrations of oxalate and sulfate ions. It appears that in the oxalate concentration range of $1 \times 10^{-3}$ to $4 \times 10^{-2} \mathrm{~mol} \cdot \mathrm{L}^{-1}$, the experimental values of $E_{1 / 2}$ somewhat exceed the calculated ones. This result suggests formation of the ternary species $\mathrm{Mn}\left(\mathrm{SO}_{4}\right)(\mathrm{ox})^{2-}$ in solution, which dominates in this oxalate concentration region. Its stability constant was estimated to be $10^{3.08}$. The distribution of $\mathrm{Mn}(\mathrm{II})$ among different species in $\mathrm{Na}_{2} \mathrm{SO}_{4}$ solutions is shown in Fig. 8. 
The diffusion coefficient of the $\mathrm{Mn}\left(\mathrm{SO}_{4}\right)(\mathrm{ox})^{2-}$ complex species was determined in a similar manner to that reported above, from the limiting current of the $\mathrm{Mn}$ (II) wave recorded at various concentration of oxalate ions in $\mathrm{Na}_{2} \mathrm{SO}_{4}$ solutions. Its value is given in Table 3 .

The reduction mechanism in this system is similar to that in $\mathrm{NaClO}_{4}$ solutions; the free $\mathrm{Mn}(\mathrm{II})$ aqua ion is the only species being reduced on the mercury electrode, whereas in the solutions five complexes exist in labile equilibrium, namely: $\mathrm{Mn}\left(\mathrm{SO}_{4}\right), \mathrm{Mn}\left(\mathrm{SO}_{4}\right)(\mathrm{ox})^{2-}$, $\mathrm{Mn}(\mathrm{ox}), \mathrm{Mn}(\mathrm{ox})_{2}^{2-}$ and $\mathrm{Mn}(\mathrm{ox})_{3}^{4-}$. The complex equilibria may be described by the following scheme, were the numerical values are base 10 logarithms of the corresponding equilibrium constants:

5.37

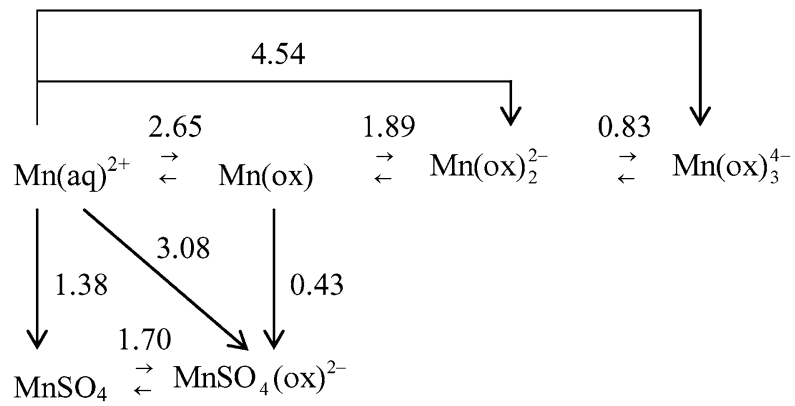

\section{Conclusions}

Since manganese is both a toxic and a biologically essential trace metal, its speciation is of fundamental importance for better understanding of its role in biological reactions.

A careful analysis of the dependence of the current-potential curves on the concentration of free ligand enabled the determination of the composition of the species reduced at the mercury electrode and of those existing in the solutions.

Reported potentiometric and conductometric studies indicated the formation of only one $\mathrm{Mn}(\mathrm{II})$-oxalate complex, i.e. $\mathrm{Mn}(\mathrm{ox})$ (Table 1). In contrast, the polarographic measurements reported here indicate the formation of two other complexes: $\mathrm{Mn}(\mathrm{ox})_{2}^{2-}$ and $\mathrm{Mn}(\mathrm{ox})_{3}^{4-}$ in perchlorate solution and the ternary species $\mathrm{Mn}\left(\mathrm{SO}_{4}\right)(\mathrm{ox})^{2-}$ in sulfate solution, and allowed the determination of their stability constants with relatively high precision.

$\mathrm{Mn}$ (II) complexes are characterized by low stability. The values of $\beta$ obtained in this work for Mn(II)-oxalate complexes are concordant with those determined for other divalent metal ions. The radius of $\mathrm{Mn}$ (II) lies between those of $\mathrm{Mg}$ (II) and $\mathrm{Ca}$ (II). The half-filled $3 \mathrm{~d}^{5}$ shell of the $\mathrm{Mn}$ (II) ion causes it to behave as a spherically polarizable ion, with no crystalfield stabilization energy; hence regarding the structure of its complexes it will behave in a manner intermediate between those of $\mathrm{Mg}$ (II) and $\mathrm{Ca}$ (II). Comparison of the values of $\beta$ for oxalate complexes of these three divalent cations (Table 4) led to the conclusion that $\mathrm{Mn}$ (II) binds to oxalate ions with a strength roughly equal to that for $\mathrm{Ca}(\mathrm{II})$ and only slightly more strongly than that for $\mathrm{Mg}$ (II). On the other hand, the obtained values of $\beta$ for $\mathrm{Mn}$ (II)-oxalate complexes also display good concordance with those of $3 \mathrm{~d}$ transition metal ions complexes and follow the Irving-Williams sequence: $\mathrm{Mg}<\mathrm{Mn} \cong \mathrm{Ca}<\mathrm{Fe}<\mathrm{Co}<\mathrm{Ni}<\mathrm{Cu}>\mathrm{Zn}$.

Open Access This article is distributed under the terms of the Creative Commons Attribution Noncommercial License which permits any noncommercial use, distribution, and reproduction in any medium, provided the original author(s) and source are credited. 
Table 4 Stability constants of selected oxalate complexes

\begin{tabular}{lllll}
\hline Metal & $\log _{10} \beta_{1}$ & $\log _{10} \beta_{2}$ & $\log _{10} \beta_{3}$ & Ref. \\
\hline $\mathrm{Ca}(\mathrm{II})$ & 2.69 & 4.04 & 5.16 & {$[6]$} \\
$\mathrm{Mg}(\mathrm{II})$ & 2.39 & & & {$[6]$} \\
$\mathrm{Mn}(\mathrm{II})$ & 2.65 & 4.54 & 5.37 & Present work \\
$\mathrm{Fe}(\mathrm{II})$ & 3.05 & 5.15 & & {$[34]$} \\
& & 4.52 & 5.22 & {$[35]$} \\
$\mathrm{Co}(\mathrm{II})$ & 3.51 & 6.38 & & {$[36]$} \\
$\mathrm{Ni}(\mathrm{II})$ & 4.26 & 7.54 & & {$[17]$} \\
$\mathrm{Cu}(\mathrm{II})$ & 5.80 & 8.08 & & {$[36]$} \\
$\mathrm{Zn}(\mathrm{II})$ & 3.72 & 6.45 & & {$[37]$} \\
\hline
\end{tabular}

\section{References}

1. Gerber, G.B., Leonard, A., Hantson, Ph.: Carcinogenicity, mutagenicity and teratogenicity of manganese compounds. Crit. Rev. Oncol./Hematol. 42, 25-34 (2002)

2. Pearson, G.F., Greenway, G.M.: Recent developments in manganese speciation. Trends Anal. Chem. 24, 803-809 (2005)

3. Michalke, B.: Manganese speciation using capillary electrophoresis-ICP-mass spectrometry. J. Chromatogr. A 1050, 69-76 (2004)

4. Takeda, A.: Manganese action in brain function. Brain Res. Rev. 41, 79-87 (2003)

5. Hue, N.V., Vega, S., Silva, J.A.: Manganese toxicity in a Hawaiian oxisol affected by soil pH and organic amendments. Soil Sci. Soc. Am. J. 65, 153-160 (2001)

6. Sillen, L.G., Martell, A.E.: Stability Constants of Metal-Ion Complexes. Special Publ., vol. 17. Chemical Society, London (1964)

7. Smith, R.M., Martell, A.E.: Critical Stability Constants. Inorganic Complexes, vol. 4. Plenum Press, New York (1976)

8. Pettit, L.D., Powell, K.J.: Stability Constants SC-Database, IUPAC and Academic Software (19932000)

9. Pędras, M., John, E.: Stability of Mn(II) complexes with acetic acid derivatives. Pol. J. Chem. 81, 17011706 (2007)

10. Verdier, E., Piro, J.: Étude de la décharge du manganése-II sur une électrode a gouttes de mercure(I). J. Chim. Phys. 65, 1052-1059 (1968)

11. Verdier, E., Piro, J.: Étude des différentes méthodes de détermination des constantes de formation d'ions métalliques complexes par polarographie. Ann. Chim. (Fr.) 4, 213-225 (1969)

12. Magers, K.D., Smith, C.G., Sawyer, D.T.: Polarographic and spectroscopic studies of the manganese(II), -(III), and -(IV) complexes formed by polyhydroxy ligands. Inorg. Chem. 17, 515-523 (1978)

13. Nagy, L., Horvath, I., Burger, K.: The electrochemical investigation of the manganese complexes of lactobionic acid. Inorg. Chim. Acta 107, 179-185 (1985)

14. Urbańska, J., Kozłowski, H.: Polarographic studies of copper(II), nickel(II) and cobalt(II) complexes with D-mannosamine. J. Coord. Chem. 21, 175-182 (1990)

15. Urbańska, J., Podsiadły, H.: Interaction of niacin with nickel(II) ions. J. Electroanal. Chem. 637, 55-62 (2009)

16. Gaur, J.N., Goswami, N.K.: Kinetics of the reduction of $\mathrm{Mn}^{2+}$ at the dropping mercury electrode. Electrochim. Acta 12, 1483-1488 (1967)

17. Urbańska, J., Biernat, J.: Evaluation of stability constants of complexes based on irreversible polarographic waves with variable electrode mechanism. Part II. The $\mathrm{Ni}^{2+}-\mathrm{C}_{2} \mathrm{O}_{4}^{2-}$ system. J. Electroanal. Chem. 130, 141-151 (1981)

18. Crow, D.R.: Diffusion phenomena and metal complex formation equilibria. J. Chem. Soc. Faraday Trans. I, 84, 4285-4297 (1988)

19. Biernat, J., Baranowska-Źrałko, M.: Evaluation of stability constants of complexes from irreversible polarographic waves. Electrochim. Acta 17, 1867-1875 (1972)

20. Biernat, J.: Evaluation of stability constants of complexes on the basis of polarographic data on irreversible electrode reactions. In: Theory and Structure of Complex Compounds, pp. 628-636. Pergamon Press, London (1964) 
21. De Ford, D.D., Hume, D.N.: The determination of consecutive formation constants of complex ions from polarographic data. J. Am. Chem. Soc. 73, 5321-5322 (1951)

22. Reddy, P., Rao, V.: Role of secondary ligands in the structure and stability of metal-citidine complexes in solution. Polyhedron 4, 1603-1609 (1985)

23. Gelles, E., Hay, R.M.: The interaction of transition-metal ions with oxaloacetic acid. Part I. The role of chelate compounds in the decarboxylation. J. Chem. Soc. 3673-3683 (1958)

24. McAuley, A., Nancollas, G.: Thermodynamics of ion association. Part VII. Some transition-metal oxalates. J. Chem. Soc. 2215-2221 (1961)

25. Money, R.W., Davies, C.W.: Complex formation in salt solutions. Part I. J. Chem. Soc. 400-403 (1934)

26. Money, R.W., Davies, C.W.: The solubility of barium oxalate in aqueous salt solutions. J. Chem. Soc. 2098-2100 (1938)

27. Stary, J.: Systematic study of the solvent extraction of metal oxinates. Anal. Chim. Acta 28, 132-149 (1963)

28. Heyrovský, J., Kuta, J.: Principle of Polarography, p. 82. Academic Press, New York (1966)

29. Jain, D.S., Goswami, N.K., Gaur, J.N.: Reduction of some quasi-reversibly reduced complexes of manganese(II) at the DME. Electrochim. Acta 13, 1757-1763 (1968)

30. Tur'yan, Ya.I., Ruvinsky, O.E.: Wlijanie kompleksoobrazujuszczich anionow na kataliticzeskije polarograficzeskije toki piridinowogo i tiomoczewinnogo kompleksow nikela(II). Opredelenie konstant nestojkosti kompleksow. Electrokhimiya 7, 483-486 (1971)

31. Tanaka, N., Ogino, H.: Polarographic determination of the formation constant of sulfatonickel(II) complex. Bull. Chem. Soc. Jpn. 34, 1040-1045 (1961)

32. Nyholm, L., Wikmark, G.: Precise polarographic determination of the stability constants of cadmium and lead with oxalate and sulphate. Anal. Chim. Acta 223, 429-440 (1989)

33. Vega, M., Pardo, R., Herguedas, M.M., Barrado, E., Castrillejo, Y.: Pseudopolarographic determination of stability constants of labile zinc complexes in fresh water. Anal. Chim. Acta 310, 131-138 (1995)

34. Bottari, E., Ciavatta, L.: Studio potenziometrico dei complesse Fe(II)-ossalato. Gazz. Chim. Ital. 95, 908-920 (1965)

35. Schaap, W.B., Laitinen, H.A., Bailar, J.C.: Polarography of iron oxalates, malonates and succinates. J. Am. Chem. Soc. 76, 5868-5872 (1954)

36. Urbańska, J., Biernat, J.: Evaluation of stability constants of complexes based on irreversible polarographic waves with variable electrode mechanism. Part I. The $\mathrm{Co}^{2+}-\mathrm{C}_{2} \mathrm{O}_{4}^{2-}$ system. J. Electroanal. Chem. 130, 123-140 (1981)

37. Berbel, F., Diaz-Cruz, J.M., Ariño, C., Esteban, M.: Voltammetry of sparingly soluble metal complexes: a differential pulse polarographic study of the Zn(II) + oxalate system. J. Electroanal. Chem. 475, 99-106 (1999) 